Article

\title{
Corrosion Behavior of AISI 304 Stainless Steel Reinforcements in SCBA-SF Ternary Ecological Concrete Exposed to $\mathrm{MgSO}_{4}$
}

\author{
Hilda A. Ariza-Figueroa ${ }^{1}$, Juan Bosch ${ }^{2}{ }^{\circledR}$, Miguel Angel Baltazar-Zamora ${ }^{3, *}$, René Croche ${ }^{4}$, \\ Griselda Santiago-Hurtado ${ }^{5}$, Laura Landa-Ruiz ${ }^{3}$, José M. Mendoza-Rangel ${ }^{6}{ }^{\circ}$, \\ José M. Bastidas ${ }^{7}$, Facundo Almeraya-Calderón ${ }^{8, *(D)}$ and David M. Bastidas ${ }^{2, *(D)}$ \\ 1 Facultad de Ingeniería Mecánica y Eléctrica (FIME), Doctorado en Ingeniería, Universidad Veracruzana, \\ Xalapa 91000, Veracruz, Mexico; hilda_af@hotmail.com \\ 2 Department of Chemical, Biomolecular, and Corrosion Engineering, National Center for Education and \\ Research on Corrosion and Materials Performance (NCERCAMP-UA), The University of Akron, \\ 302 E Buchtel Ave, Akron, OH 44325-3906, USA; jb394@zips.uakron.edu \\ 3 Facultad de Ingeniería Civil-Xalapa, Universidad Veracruzana, Lomas del Estadio S/N, Zona Universitaria, \\ Xalapa 91000, Veracruz, Mexico; lalanda@uv.mx \\ 4 Facultad de Ingeniería Mecánica y Eléctrica, Universidad Veracruzana, Xalapa 91000, Veracruz, Mexico; \\ rcroche@uv.mx \\ 5 Facultad de Ingeniería Civil—Unidad Torreón, Universidad Autónoma de Coahuila, Torreón 27276, Mexico; \\ grey.shg@gmail.com \\ 6 Facultad de Ingeniería Civil, Universidad Autónoma de Nuevo León, Ave. Pedro de Alba S/N, \\ Ciudad Universitaria, San Nicolás de los Garza 66455, Mexico; jmmr.rangel@gmail.com \\ 7 National Centre for Metallurgical Research (CENIM), CSIC, Ave. Gregorio del Amo 8, 28040 Madrid, Spain; \\ bastidas@cenim.csic.es \\ 8 Universidad Autónoma de Nuevo León, FIME-CIIIA, Av. Universidad S/N, Ciudad Universitaria, \\ San Nicolás de los Garza 66455, Mexico \\ * Correspondence: mbaltazar@uv.mx (M.A.B.-Z.); falmeraya.uanl.ciiia@gmail.com (F.A.-C.); \\ dbastidas@uakron.edu (D.M.B.); Tel.: +52-2282-5252-94 (M.A.B.-Z.); +52-6144-2762-73 (F.A.-C.); \\ $+1-330-972-2968$ (D.M.B.)
}

Received: 26 April 2020; Accepted: 20 May 2020; Published: 24 May 2020

check for updates

\begin{abstract}
In this study, ternary ecological concrete (TEC) mixtures were produced with partial substitution of the ordinary Portland cement (OPC) by $10 \%, 20 \%$, and $30 \%$ of sugar cane bagasse ash (SCBA) and silica fume (SF); a control mixture (100\% OPC) was prepared according to ACI 211.1 standard. The studied TEC specimens were reinforced with AISI 304 stainless steel and AISI 1018 carbon steel rebars. TEC reinforced specimens were immersed in two different electrolytes, a control (DI-water) and $3.5 \mathrm{wt} . \% \mathrm{MgSO}_{4}$ solution, for 180 days. The electrochemical corrosion was monitored by corrosion potential $\left(E_{c o r r}\right)$ according to ASTM C-876-15 standard, and the linear polarization resistance (LPR) technique using ASTM G59 standard. The $E_{\text {corr }}$ and current density $i_{\text {corr }}$ results show that AISI 304 stainless steel rebars have a high corrosion resistance, with $i_{\text {corr }}$ values below $0.1 \mu \mathrm{A} / \mathrm{cm}^{2}$, which is interpreted as a level of negligible corrosion. The best corrosion performance was found for the TEC mixture made with a $20 \%$ addition of blend of sugar cane bagasse ash-silica fume (SCBA-SF) to the OPC.
\end{abstract}

Keywords: corrosion; ternary ecological eoncrete; sugar cane bagasse ash; silica fume; AISI 304; sulfates 


\section{Introduction}

Concrete is the most widely used building material worldwide, owing to its excellent physical properties including excellent mechanical properties and durability. Reinforced concrete is of paramount importance for the development of societies, which demand advanced civil engineering structures and infrastructure, such as bridges, buildings, pavements, dams, pipelines, and canisters, among others. However, the corrosion of reinforcing steel in concrete is the main cause of premature deterioration of the infrastructure and one of the most important issues for the maintenance of the structural integrity, which dramatically impacts economy [1-6]. The corrosion of steel embedded in concrete is an electrochemical process influenced by the chloride ingress and carbonation [7].

The use of stainless steel (SS) reinforcement is an efficient method for preventing the corrosion of reinforced concrete (RC) structures [8,9]. Ferritic and austenitic stainless steels were the first SS reinforcements developed; currently, the tendency is the use of duplex SS (DSS). The SS passivates in the atmosphere, but when in contact with the alkaline environment of the concrete, this passive layer is not stable and a new passivation process takes place [10-12]. Several studies with stainless steels reported their good corrosion resistance in chloride polluted environments, which vary in function of the SS chemical composition, the type of test performed (accelerated, natural), and the media (pore solution, mortar, or concrete) [13-19].

The corrosion process can be caused by several factors, the most significant of which is the entry of the aggressive ions, such as chlorides present in marine environments [20-22] and sulfates, which are inorganic salts normally present in the ground [23-26], as well as in groundwater and in surface water, although the degree of concentration can be highly variable. The presence of sulfates in water in contact with a hardened cement paste can significantly increase the solubility of components of the concrete admixture and cause degradation of concrete through leaching; therefore, the steel remains unprotected [27-29]. This concrete degradation can lead to a severe structural failure as the reinforcement material is more susceptible to corrosion processes. Through the use of non-destructive tests (NDTs) and/or analytical formulation, which are fast and high quality methods to assess the corrosion of reinforcing steel, according to the determination of the lost cross section of the bar, using novel analytical models [30], the section loss due to corrosion products at the steel/concrete interface of specimens subjected to different environments has originated a generalized concept of paste filled with corrosion product (CP) [31]. A widely used strategy to mitigate this reinforcement corrosion is to use coatings in order to substantially increase the durability of the structure. A similar effect can be generated using additives to the concrete such as sealants that improve the corrosion protection of the reinforcement. Moreover, laboratory simulations show that the concrete reinforced with galvanized steel is better in an aggressive environment, as well as resisting contaminants found present in the concrete mixture itself [32-34].

The production of ordinary Portland cement (OPC) generates between $5 \%$ and $8 \% \mathrm{CO}_{2}$ total emissions to the environment and could increase to between $10 \%$ and $15 \%$ in the future [35]. Therefore, different approaches and solutions to retard or reduce the corrosion process and mitigate emissions produced from the cement industry have been investigated. The solutions proposed to reduce these high emissions include new alkali-activated materials, such as fly ash (FA), slags, or metakaolin, among others [36]. Furthermore, in the last 20 years, sugar cane bagasse ash (SCBA) and rice husks ash (RHA) have been studied in order to provide a more sustainable and equally performing solution for reinforced structures $[37,38]$ coming from agricultural waste, as less FA resources were available owing to the coal regulations [39]. SCBA is a sugar mill byproduct obtained from the bagasse combustion that, after being treated, can be used a concrete binder thanks to its pozzolanic activity. However, few corrosion studies have been performed for all these novel reinforced concretes. For that reason, the most conservative approach, because of the lack of agreement about their corrosion performance, is to use them as supplementary cementitious materials (SCMs), gradually replacing the OPC with low quantities of the novel materials. This replacement is an environmentally friendly, and cost-effective solution owing to the by-products nature of these novel materials [40,41]. Another important factor 
of these novel materials is that they cure faster than OPC [42], making them even more suitable for precast components.

These SCMs promote a reaction known as the pozzolanic reaction, wherein the $\mathrm{Ca}(\mathrm{OH})_{2}$ from the hydration process reacts with these additives, decreasing the porosity and permeability of the concrete [43]. The benefits were mainly derived from the presence of a high $\mathrm{SiO}_{2}$ content and amorphous mineralogical character in the SCMs, allowing the calcium hydroxide (free lime forms during cement hydration) to react with the silica content present in the pozzolanic materials and water, which forms additional calcium silicate hydrate; this is called secondary gel, hence the compressive strength is enhanced [44]. Ultra-fine particles of silica fume enhance the concrete in the hardened state by acting as a micro filling material in the concrete, which fills the micro-voids in concrete. Densification of the interfacial transition zone also takes place, as well as further enhancing of the matrix aggregate bond-the enhancement in strength due to the additional formation of C-S-H gel resulting from the pozzolanic reaction between silica fume and calcium hydroxide [45]. Several SCMs have been reported to have different behaviors regarding chloride ingress, carbonation, and sulfates resistance. Even between the same materials, different behaviors were reported, leading to a lack of agreement. For instance, FA reported a higher chloride ingress resistance than OPC [46,47], but a similar chloride penetration was also reported by Ganesa et al. [48]. By adding metakaolin to the FA, not only is the geopolymerisation process enhanced, but also the porosity is decreased, hence improving the chloride ingress resistance $[49,50]$. However, the slags contribute to improved carbonation and chloride ingress resistance, as stated by Navarro et al. [51]. Silica fume (SF) addition to OPC showed decreased chloride threshold values [52], but an increased chloride resistance performance was shown in different studies at the same time [53,54]. It also increases the freeze-thaw resistance, as stated by Gruszczyński et al. [55]. Although SCBA has workability issues, an addition between $10 \%$ and $30 \%$ as an OPC replacement to the mixture reduces not only the permeability, but also the diffusion of chloride ions through the concrete [56-61]. However, the post-treatment can also affect these results by increasing the greenhouse emissions or by decreasing the workability of these concretes, apart from the mechanical and chemical properties as stated by Franco-Luján et al. [61]. As can be seen from the literature review, there is an existing lack of agreement between authors about the corrosion performance of these novel materials. This lack of agreement might be because of the manufacturing processes, mixture design, curing conditions, or exposure conditions. For that reason, further development has to be done in order to determine the mechanisms behind this corrosion performance behavior and to generate a solution to the high pollutant OPC.

The aim of this work was to study the corrosion behavior of partially substituted SCBA and SF ternary ecological concrete (TEC) mixtures embedding AISI 304 SS and AISI 1018 carbon steel (CS) rebars. TEC has been used as an alternative material to OPC in this work owing to its pozzolanic characteristics [62], as partial substitutes of the OPC, to generate a reduction in $\mathrm{CO}_{2}$ and achieve improvements in the concrete properties to improve their performance against corrosion of the reinforcing steel, as has been proposed in some recent projects [63,64]; few proposals have used it for soil improvement [65]. Four concrete mixtures were produced according to the ACI 211.1 standar [66], the first with $100 \%$ OPC, while the remaining three were prepared with substitutions partially in percentages of $10 \%, 20 \%$, and $30 \%$ of the OPC in combination with SCBA and SF TEC.

\section{Materials and Methods}

\subsection{Ternary Ecological Concrete}

In this investigation, OPC was used, in accordance with the NMX C-414 standard of the ONNCCE [67]. SCBA and SF were used as partial substitutes for OPC with replacement percentages of $10 \%, 20 \%$, and $30 \%$, thus producing TEC mixtures. The SCBA was obtained from Sugar Mills Mahuixtlan, located in Coatepec, Mexico. The SCBA was sampled from one of the boilers where the combustion temperature reached $750{ }^{\circ} \mathrm{C}$. The SF used was purchased from a commercial supplier. 
The physical characterization of the aggregates was performed, according to the following tests: ASTM C33/C33M-16e1 (Standard Specification for Concrete Aggregates) to determine the fineness modulus and maximum aggregate size [68], ASTM C29/C29M-07 (Standard Test Method for Bulk Density (Unit Weight) and Voids in Aggregate) [69], ASTM standards: ASTM C-127-15 (Standard Test Method for Relative Density (Specific Gravity) and Absorption of Coarse Aggregate) [70], and ASTM C-128-15 (Standard Test Method for Relative Density (Specific Gravity) and Absorption of Fine Aggregate) [71]. All the results obtained from the physical characterization of the aggregates are summarized in Table 1.

Table 1. Results of the characterization of the aggregates, obtained according to ASTM standards.

\begin{tabular}{cccc}
\hline \multirow{2}{*}{ Physical Properties of Materials } & Standard & \multicolumn{2}{c}{ Aggregate } \\
\cline { 3 - 4 } & & Coarse & Fine \\
\hline Maximum Aggregate Size $(\mathrm{mm})$ & ASTM C33/C33M-16e1 & 19.05 & - \\
Bulk Density (Unit Weight) $\left(\mathrm{kg} / \mathrm{m}^{3}\right)$ & ASTM C29/C29M-07 & 1433 & 1695 \\
Relative Density (Specific Gravity) & ASTM C-127-15 ASTM C-128-15 & 2.6 & 2.2 \\
Absorption (\%) & ASTM C-127-15ASTM C-128-15 & 1.7 & 1.8 \\
Fineness Modulus & ASTM C33/C33M-16e1 & - & 2.94 \\
\hline
\end{tabular}

\subsection{Proportioning of Concrete Mixtures}

Concrete mixtures were designed in accordance to ACI 211.1 method [66], the most used design method for concrete research [72-75]. This method is based on the physical properties for coarse and fine aggregates, see Table 1.

Four different hydraulic concrete mixtures were prepared, with the control mixture with $100 \%$ OPC and three mixtures with partial substitution of $10 \%, 20 \%$, and $30 \%$ of the OPC with combinations of SCBA-SF. Table 2 the shows the dosage used for each concrete mixture, considering the four concrete mixes an $\mathrm{F}^{\prime} \mathrm{C}=29.4 \mathrm{MPa}$ (compressive strength).

Table 2. Proportioning of concrete mixtures in $\mathrm{kg}$ for $1 \mathrm{~m}^{3}$ of concrete $\left(\mathrm{F}^{\prime} \mathrm{C}=29.4 \mathrm{MPa}\right)$. OPC, ordinary Portland cement; SBCA, sugar cane bagasse ash; FA, fly ash.

\begin{tabular}{ccccc}
\hline Materials & $\mathbf{1 0 0} \%$ OPC & $\mathbf{1 0} \%$ SCBA-SF & $\mathbf{2 0} \% \mathbf{~ S C B A - S F}$ & $\mathbf{3 0} \% \mathbf{S C B A - S F}$ \\
\hline Cement & 315 & 283.50 & 252.00 & 220.50 \\
Water & 205 & 205 & 205 & 205 \\
SCBA & 0 & 15.75 & 31.50 & 47.25 \\
SF & 0 & 15.75 & 31.50 & 47.25 \\
Coarse aggregate & 886 & 886 & 886 & 886 \\
Fine aggregate & 770 & 770 & 770 & 770 \\
\hline
\end{tabular}

\subsection{Characterization of Fresh and Hardened Concrete}

The characterization of fresh concrete was performed using slump testing, temperature measurements, and volumetric mass (density) measurements performed according to ONNCCE and ASTM standards; the results obtained for each mixture can be seen in Table 3 .

Table 3. Physical properties of individual employees.

\begin{tabular}{ccccc}
\hline Test & $\mathbf{1 0 0} \%$ OPC 30R & $\mathbf{1 0 \%}$ SCBA-SF & $\mathbf{2 0 \%}$ SCBA-SF & 30\% SCBA-SF \\
\hline Slump, $\mathrm{cm} \mathrm{[76]}$ & 7.0 & 6.0 & 5.5 & 5.0 \\
Temperature, ${ }^{\circ} \mathrm{C}[77]$ & 24.0 & 23.5 & 23.5 & 22.5 \\
Density, $\mathrm{kg} / \mathrm{m}^{3}[78]$ & 2345.83 & 2307.29 & 2301.04 & 2276.04 \\
\hline
\end{tabular}


Table 4 presents the results of the compressive strength (concrete in the cured state) of the four mixtures studied, and assays were performed after 7, 14, and 28 days, as indicated by the standard NMX-C-083-ONNCCE-2002 [79].

Table 4. Compressive strength at 7, 14, and 28 days ( $\mathrm{F}^{\prime} \mathrm{C}$ in $\left.\mathrm{MPa}\right)$.

\begin{tabular}{cccc}
\hline \multirow{2}{*}{ Concrete Mixture } & \multicolumn{3}{c}{ Compressive Strength (MPa) } \\
\cline { 2 - 4 } & 7 Days & 14 Days & 28 Days \\
\hline MC = 100\% OPC & 24.3 & 28.3 & 31.2 \\
M10 = 10\% (SCBA-SF) & 21.5 & 25.5 & 28.6 \\
M20 = 20\% (SCBA-SF) & 22.4 & 26.1 & 30.0 \\
M30 = 30\% (SCBA-SF) & 16.7 & 21.1 & 24.1 \\
\hline
\end{tabular}

\subsection{Characteristic and Nomenclature of Test Specimens}

The control OPC mixture and the three mixtures of TEC were made a with water-to-cement ratio of 0.65 . The specimens were prisms of with dimensions of $15.0 \times 15.0 \times 15.0 \mathrm{~cm}$. In all the specimens, AISI 304 and AISI 1018 steel bars were embedded. The steel bars had a length of $15 \mathrm{~cm}$ and $9.5 \mathrm{~mm}$ diameter. The curing of all specimens was carried out by immersion in DI-water for 27 days, according to NMX-C-159 standard [80]. After the curing period, the eight specimens were placed in the exposure media, four specimens were immersed in DI-water (control medium), and the remaining four were immersed in $3.5 \mathrm{wt} . \% \mathrm{MgSO}_{4}$ solution for 175 days, simulating a sulfated medium or aggressive medium. The specimens were then subjected to electrochemical tests. Table 5 shows the elemental composition analyzed by X-ray fluorescence spectroscopy (XRF) of the AISI 304 austenitic stainless steel (SS) and AISI 1018 carbon steel (CS).

Table 5. Elemental composition (wt.\%) by X-ray fluorescence spectroscopy (XRF) analysis of the reinforcements tested, AISI 1018 carbon steel (CS) and AISI 304 stainless steel (SS).

\begin{tabular}{ccccccccccc}
\hline \multirow{2}{*}{ Steel } & \multicolumn{10}{c}{ Element, wt.\% } \\
\cline { 2 - 11 } & $\mathbf{C}$ & Si & Mn & P & S & Cr & Ni & Mo & Cu & Fe \\
\hline AISI 1018 CS & 0.20 & 0.22 & 0.72 & 0.021 & 0.020 & 0.13 & 0.06 & 0.02 & 0.18 & Balance \\
AISI 304 SS & 0.04 & 0.32 & 1.75 & 0.032 & 0.001 & 18.20 & 8.13 & 0.22 & 0.21 & Balance \\
\hline
\end{tabular}

The nomenclature used for the electrochemical monitoring of corrosion potential and corrosion kinetics of AISI 304 SS and AISI 1018 CS embedded in TEC, exposed to DI-water (control medium) and 3.5 wt. $\% \mathrm{MgSO}_{4}$ solution (aggressive medium), is shown in Table 6.

Table 6. Nomenclature of specimens tested for a period of 180 days.

\begin{tabular}{ccccc}
\hline \multirow{2}{*}{ Sample/Concrete Composition } & \multicolumn{4}{c}{ Electrolytes } \\
\cline { 2 - 5 } & \multicolumn{2}{c}{ DI-Water } & \multicolumn{2}{c}{ Solution 3.5 wt.\% MgSO $_{4}$} \\
\cline { 2 - 5 } & AISI 1018 & AISI 304 & AISI 1018 & AISI 304 \\
\hline MC: Control/100\% OPC & MC-1-18 & MC-1-304 & MC-2-18 & MC-2-304 \\
M10: Mixture/90\% OPC, 10\% SCBA-SF & M10-1-18 & M10-1-304 & M10-2-18 & M10-2-304 \\
M20: Mixture/80\% OPC, 20\% SCBA-SF & M20-1-18 & M20-1-304 & M20-2-18 & M20-2-304 \\
M30: Mixture/70\% OPC, 30\% SCBA-SF & M30-1-18 & M30-1-304 & M30-2-18 & M30-2-304 \\
\hline
\end{tabular}

Prismatic-reinforced TEC specimens were manufactured using AISI 1018 CS and AISI 304 SS reinforcements, with a $15 \mathrm{~cm}$ length and $9.5 \mathrm{~mm}$ diameter, as depicted in Figure 1. Each of the bars were coated $4 \mathrm{~cm}$ from the top and $4 \mathrm{~cm}$ from the bottom, in order to delimit the area of exposure to corrosion of steel in concrete with a length of $5 \mathrm{~cm}$. 


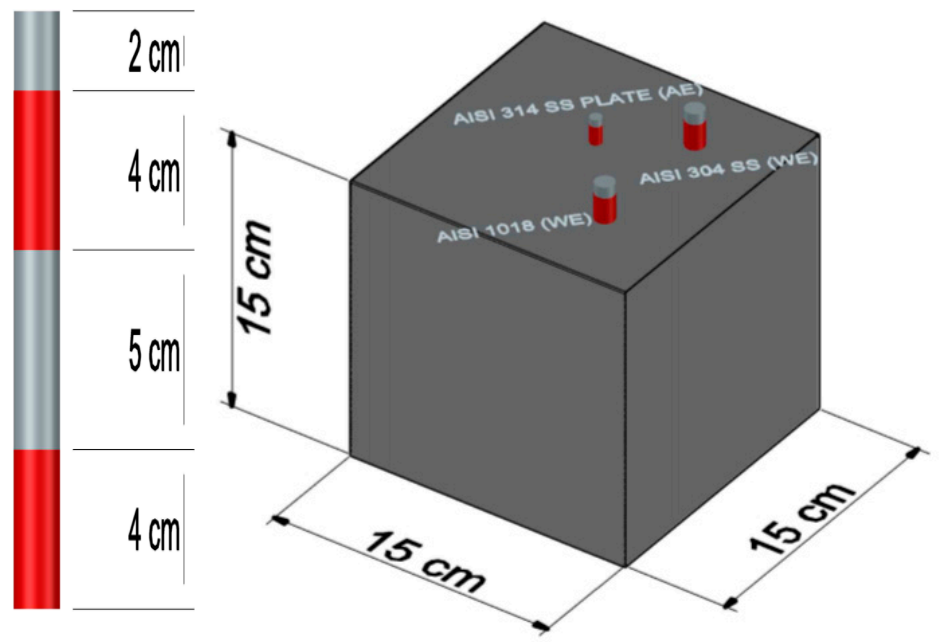

Figure 1. Experimental design of the rebars and concrete specimens.

TEC specimens were exposed to two different electrolytes, control medium (DI-water) and $3.5 \mathrm{wt} . \%$ $\mathrm{MgSO}_{4}$ solution, for a period of 182 days.

Electrochemical measurements were performed using a conventional three-electrode cell configuration. The AISI 1018 CS and AISI 304 SS were used as the working electrodes (WEs). A standard copper/copper sulfate $\left(\mathrm{Cu} / \mathrm{CuSO}_{4}\right)$ and a AISI $314 \mathrm{SS}$ plate were used as reference (RE) and counter electrode (AE), respectively. The half-cell corrosion potential $\left(E_{\text {corr }}\right)$ according to ASTM C876-15 standard [81] and considering one more range, according to the literature [82]. The linear polarization resistance (LPR) was recorded at a sweep rate of $10 \mathrm{mV} / \mathrm{min}$ at, a potential scan range was applied between -20 to $+20 \mathrm{mV}$ versus $\left(\mathrm{Cu} / \mathrm{CuSO}_{4}\right)$, according to ASTM G59-97 standard [83]. Electrochemical measurements were performed in a Gill AC Galvanostat/Potentiostat/ZRA (ACM Instruments, Cark in Cartmel, UK), the results were analyzed using Version 4 Analysis specialized software from ACM Instruments (Cark in Cartmel, UK) [84,85].

The TEC reinforced specimens were immersed in the $3.5 \mathrm{wt} . \% \mathrm{MgSO}_{4}$ solution at room temperature, and $E_{\text {corr }}$ and $i_{\text {corr }}$ were monitored every two weeks and all experimental measurements were carried out in triplicate.

The $i_{\text {corr }}$ and the corrosion rate $\left(v_{c o r r}\right)$ were estimated from the LPR technique using Stern and Geary Equation (1) [86]:

$$
i_{\text {corr }}=\frac{B}{R p}
$$

where $R p$ is expressed in $\Omega \cdot \mathrm{cm}^{2}$ and $B$ in $V$ is a constant resulting from a combination of the anodic and cathodic Tafel slopes; $\mathrm{B}$ is a constant with a recommended value of $0.026 \mathrm{~V}$ for active and $0.052 \mathrm{~V}$ for the passive corrosion of steel in concrete $[87,88]$.

$E_{\text {corr }}$ was used to assess the corrosion condition of reinforced concrete specimens according to ASTM C-876-15 [81], which establishes the criteria or ranges that relate the $E_{\text {corr }}$ values with the risk corrosion for embedded steel specimens made with OPC concrete and TEC, see Table 7 [81,82].

Table 7. The measured half-cell corrosion potential $\left(E_{\text {corr }}\right)$ versus a $\mathrm{Cu} / \mathrm{CuSO}_{4}$ in reinforcement concrete $[81,82]$.

\begin{tabular}{cc}
\hline$E_{\text {corr }}$ vs. CSE & Corrosion Condition \\
\hline$E_{\text {corr }}>-200$ & Low $(10 \%$ of risk corrosion $)$ \\
$-200>E_{\text {corr }}>-350$ & Intermediate corrosion risk \\
$-350>E_{\text {corr }}>-500$ & High $(<90 \%$ of risk corrosion $)$ \\
$E_{\text {corr }}<-500$ & Severe Corrosion \\
\hline
\end{tabular}


To determine $v_{c o r r}$ of steels embedded in the mixtures of conventional concrete and ternary ecological concrete, the $i_{\text {corr }}$ values were used. The criteria used to analyze the $i_{c o r r}$ results are based on the state of corrosion of steel in concrete reported in the literature [87], as shown in Table 8.

Table 8. Ranges of corrosion current density $\left(i_{\text {corr }}\right)$, and the corrosion rate $\left(v_{\text {corr }}\right)$ related to corrosion level [87].

\begin{tabular}{ccc}
\hline $\boldsymbol{i}_{\text {corr }}\left(\boldsymbol{\mu \mathrm { A }} / \mathrm{cm}^{2}\right)$ & $\boldsymbol{v}_{\text {corr }}(\mathrm{mm} / \mathbf{y})$ & Corrosion Level \\
\hline$\leq 0.1$ & $\leq 0.001$ & Negligible (Passivity) \\
$0.1-0.5$ & $0.001-0.005$ & Low Corrosion \\
$0.5-1$ & $0.005-0.010$ & Moderate Corrosion \\
$>1$ & $>0.010$ & High Corrosion \\
\hline
\end{tabular}

\section{Results and Discussion}

\subsection{Corrosion Potential}

The $E_{\text {corr }}$ of the specimens were monitored in accordance with ASTM C876-15 [81], and interpreted by the criteria presented in Table 7 [82].

\subsubsection{Behavior $E_{\text {corr }}$ Specimens in Control Medium (DI-Water)}

Figure 2 shows the corrosion potential of the AISI 1018 CS and AISI 304 SS, which are embedded in different TEC, exposed in control medium (DI-water). The MC-1-18 specimen presented $E_{c o r r}$ values of $-342 \mathrm{mV}$ in the first 14 days, within the intermediate corrosion risk range. Subsequently, the $E_{\text {corr }}$ values increase to an area of low ( $10 \%$ of risk corrosion) according to ASTM C-876-15, with $E_{\text {corr }}$ values of $-132 \mathrm{mV}$ at day 56. Moreover, the M10-1-18 specimen presents an $E_{\text {corr }}$ of $-227 \mathrm{mV}$ in the first 28 days, and decreases after day 42 , reaching a corrosion potential of $-250 \mathrm{mV}$. Afterwards, $E_{c o r r}$ remains within the area of Intermediate corrosion risk until day 90 , and then increases to the area with low (10\% of risk corrosion) until day 180.

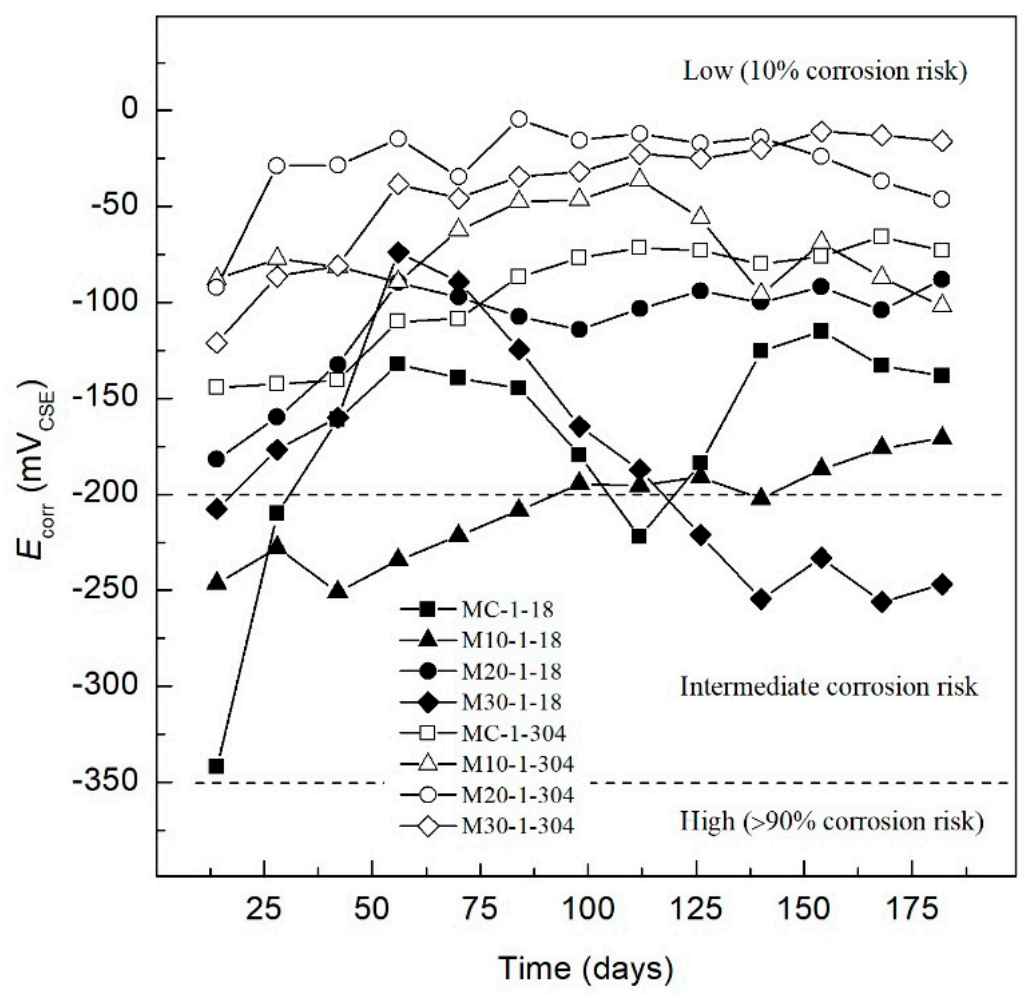

Figure 2. $E_{\text {corr }}$ of specimens exposed to control medium (DI-water). 
Meanwhile, the behavior of M20-1-18 and M30-1-18 specimens maintains a similar behavior for the first 56 days, having $E_{\text {corr }}$ values in the zone of low (10\% of risk corrosion), showing potentials of $-107 \mathrm{mV}$ and $-105 \mathrm{mV}$. However, the M20-1-18 specimen maintains a passive behavior with more positive values of $E_{\text {corr }}$ until reaching $-82 \mathrm{mV}$ on day 180 , which indicates a low ( $10 \%$ of risk corrosion). The M30-1-18 specimen from day 90 to day 180 exhibits a decrease in $E_{c o r r}$ to the intermediate corrosion risk with a value of $-246 \mathrm{mV}$.

For AISI 304 SS specimens, MC-1-304 shows initial values of $-144 \mathrm{mV}$ in the region of low $(10 \%$ of risk corrosion), maintaining an electropositive growth until the end of monitoring the same area, to $-73 \mathrm{mV}$ in 180 days. The M10-1-304, M20-1-304, and M30-1-304 specimens maintain initial and final behavior in the region of low (10\% of risk corrosion), performing better protection of TEC with substitutions of $20 \%$ and $30 \%$ of OPC by SCBA-SF combinations.

\subsection{2. $E_{\text {corr }}$ Behavior of $3.5 \mathrm{wt} . \% \mathrm{MgSO}_{4}$ Solution}

In Figure 3, in the AISI 1018 steel and 304 SS, the risk corrosion increases after being exposed to magnesium sulfate. The MC-2-18 and M10-2-18 specimens exhibit stable behavior within the area of low ( $10 \%$ of risk corrosion) with potentials of $-198 \mathrm{mV}$ and $-175 \mathrm{mV}$, respectively. Finally, day 180 shows $E_{\text {corr }}$ values of $-33 \mathrm{mV}$ and $-66 \mathrm{mV}$ for MC-2-18 and M10-2-18 specimens, respectively. Because these specimens are more electropositive, it is apparent that the mixtures provide better protection to the steel reinforcement.

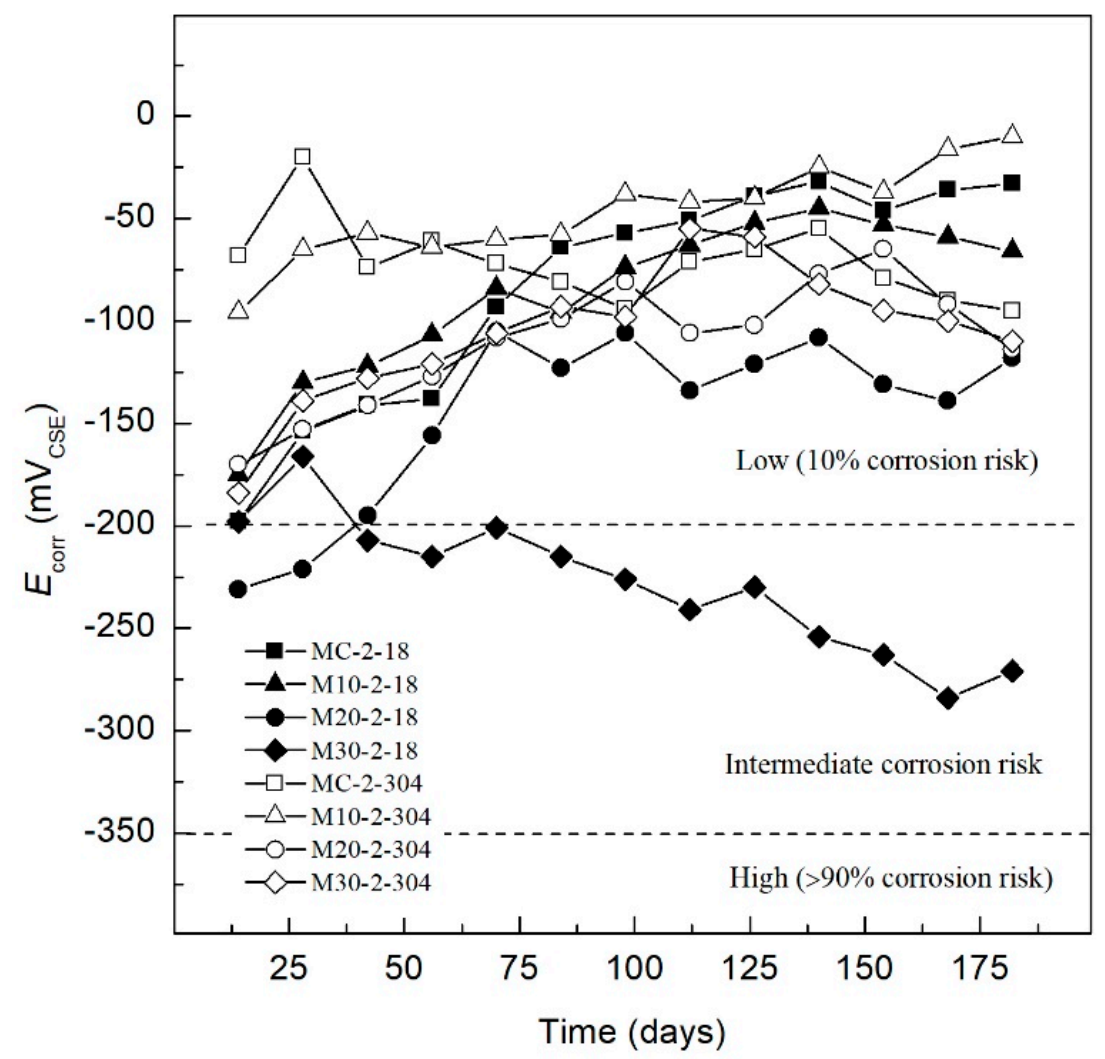

Figure 3. $E_{\text {corr }}$ of specimens exposed in 3.5 wt. $\% \mathrm{MgSO}_{4}$ solution.

This behavior has been reported in the literature, and is associated with the reaction of sulfates with hydration products, which causes the matrix of the concrete to be denser, thus reducing the network of pores and enhancing the behavior against corrosion when exposed to sulfated media [89]. Dehwah et al. reported that the presence of sulphates in chloride solution did not affect the corrosion initiation time [90]. Meanwhile, the M20-2-18 has an initial $E_{c o r r}$ of $-231 \mathrm{mV}$, within the area of uncertainty until day 28 , when the specimen presents a trend towards more positive $E_{\text {corr }}$ values 
throughout the time of exposure, remaining in a range of $-120 \mathrm{mV}$ to $-160 \mathrm{mV}$ indicating a low (10\% of risk corrosion), according to ASTM C-876-15. The initial $E_{\text {corr }}$ of sample M30-2-18 exhibits a low ( $10 \%$ of risk corrosion) and, after day 42 , the $E_{\text {corr }}$ decreases until day 180 , with a value $-271 \mathrm{mV}$ in the intermediate corrosion risk range. The MC-2-304 specimen initially presents an $E_{\text {corr }}$ value of -68 $\mathrm{mV}$, within the area of low (10\% of risk corrosion), maintaining a constant behavior within the zone. Meanwhile, MC-2-304, M10-2-304, M20-2-304, and M30-2-304 showed initial E $E_{\text {corr }}$ values less than $-200 \mathrm{mV}$, continuing with more electropositive values until day 180. The AISI 304 SS exhibits better corrosion behavior in each of the tested TEC mixtures, presenting during the 180 days of monitoring, $E_{\text {corr }}$ values that indicate low (10\% of risk corrosion) according to ASTM C-876-15. Among the TEC specimens, M10-2-304 showed the best corrosion behaviour.

\subsection{Corrosion Current Density}

The results of the $i_{\text {corr }}$ values of the AISI 304 SS and AISI 1018 CS embedded in the TEC were interpreted according to the criterion of the Table 8 .

\subsubsection{Behavior of $i_{\text {corr }}$ Specimens in Electrolyte: Control Medium (DI-Water)}

Figure 4 shows the behavior of $i_{\text {corr }}$ of the specimens exposed to control medium (DI-water). The specimens reinforced with AISI 1018 steel, MC-1-18, M-10-1-18, M20-1-18, and M30-1-18 show high $i_{\text {corr }}$ values, ranging from 0.53 to $0.28 \mu \mathrm{A} / \mathrm{cm}^{2}$, thus indicating a moderate corrosion according to criterion of the Table 8 . The $i_{\text {corr }}$ values related to the formation of the passive layer that occurs in this stage of concrete mixtures (28 days) display a steady decline in values for all specimens. By day 84 of exposure to the control medium, the $i_{\text {corr }}$ values of the specimens were less than $0.1 \mu \mathrm{A} / \mathrm{cm}^{2}$, indicating a negligible level of corrosion or a passivation state of the system. A small influence is identified between the concrete types, OPC and TEC, but owing to values below $0.1 \mu \mathrm{A} / \mathrm{cm}^{2}$, both are considered passive.

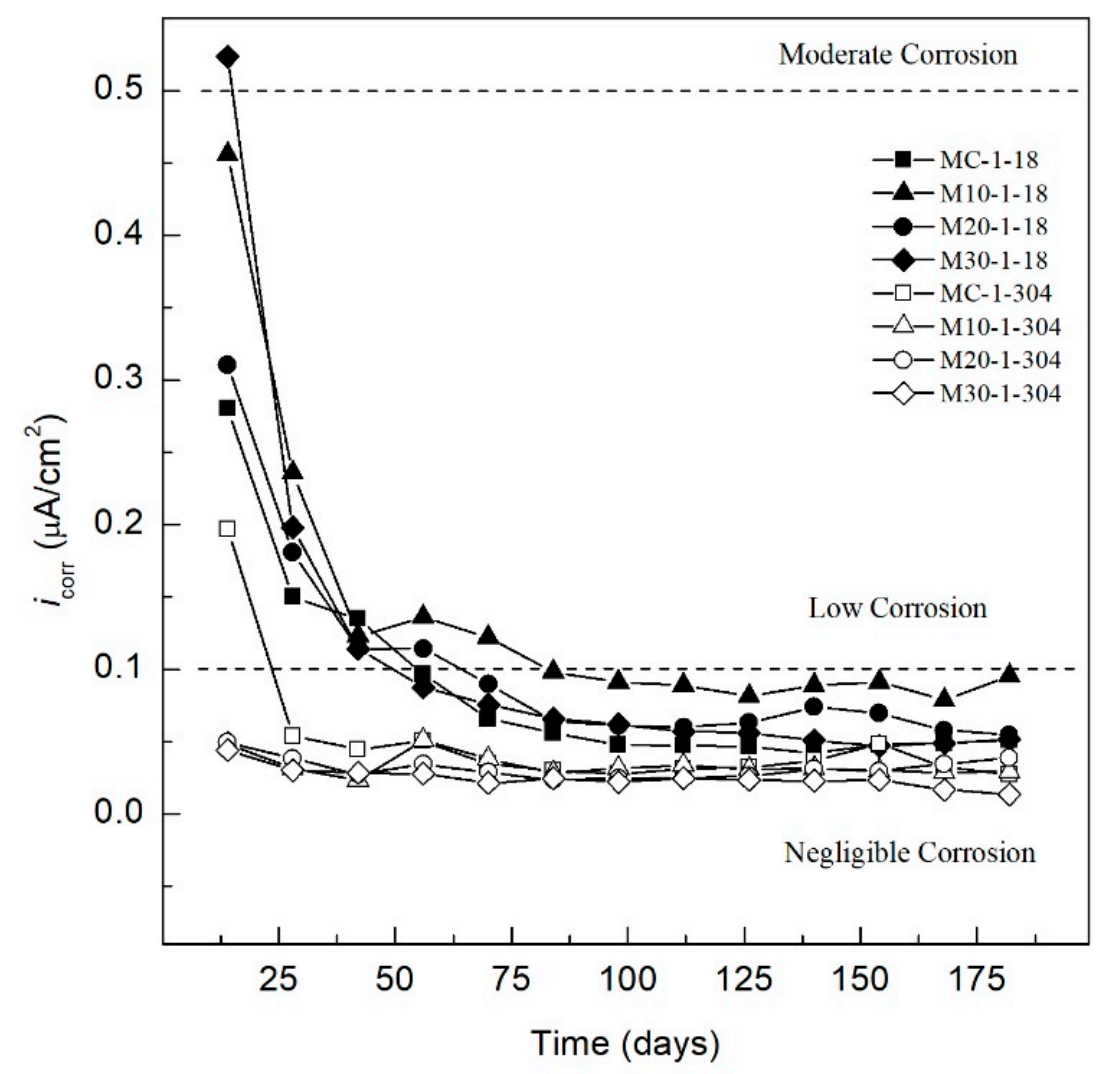

Figure 4. $i_{\text {corr }}$ specimens exposed to control medium (DI-water). 
Furthermore, the MC-1-304, M10-1-304, M20-2-304, and M30-1-304 specimens exhibit an initial $i_{\text {corr }}$ less than $1.0 \mu \mathrm{A} / \mathrm{cm}^{2}$, which indicates a negligible level of corrosion from day 14 to day 180 . The $i_{\text {corr }}$ for specimens with AISI 304 SS coincide with values reported in the literature [91,92], monitoring below $0.03 \mu \mathrm{A} / \mathrm{cm}^{2}$, as well as for AISI 1018 CS when concrete is exposed in non-aggressive environments [93].

\subsubsection{Behavior of Specimens $i_{\text {corr }}$ in Electrolyte: $\left(3.5 \mathrm{wt} . \% \mathrm{MgSO}_{4}\right.$ Solution)}

Figure 5 presents the $i_{\text {corr }}$ of AISI 304 SS and AISI 1018 CS embedded in the TEC after 180 days of exposure to the aggressive medium ( $3.5 \mathrm{wt} . \% \mathrm{MgSO}_{4}$ solution). The MC-2-18, M10-2-18, M20-2-18, and M30-2-18 specimens present passivity during the curing stage (up to 28 days), according to Table 6, with $i_{\text {corr }}$ values ranging from 0.48 to $0.08 \mu \mathrm{A} / \mathrm{cm}^{2}$. With increasing time, a trend towards values closer to $0.1 \mu \mathrm{A} / \mathrm{cm}^{2}$ can be observed, associated with passivation of the system, in agreement with the literature of concrete reinforced with AISI 1018 CS exposed to sulfates [94]. However, after 84 days of exposure, an increase in the $i_{\text {corr }}$ was observed in the M30-2-18 specimen, reaching values greater than $0.1 \mu \mathrm{A} / \mathrm{cm}^{2}$ for day 112 and $0.167 \mu \mathrm{A} / \mathrm{cm}^{2}$ for day 180, indicating a low level of corrosion and the activation of the M30-2-18 specimen. For the MC-2-18, M10-2-18, and M20-2-18 specimens, an increase in $i_{\text {corr }}$ values was observed for day 112 of exposure to the sulphates medium, associated with the activation of the steel-concrete system of the three specimens. However, the MC-2-18 specimen presents similar values to those of the M30-2-18 specimen, which exhibits an $i_{\text {corr }}$ value of $0.135 \mu \mathrm{A} / \mathrm{cm}^{2}$ at 180 days, thus displaying a better performance against corrosion than the specimen with OPC, MC-2-1. The MC-2-18 specimen shows an $i_{\text {corr }}$ passing the $0.1 \mu \mathrm{A} / \mathrm{cm}^{2}$ threshold after 140 days of exposure, ending with an $i_{\text {corr }}$ value of $0.127 \mu \mathrm{A} / \mathrm{cm}^{2}$ at 180 days of exposure, indicating the system activation and a low level of corrosion. Lastly, the specimen reinforced with AISI 1018 carbon steel, which presented the greatest resistance to corrosion when exposed to a sulphates medium, was M20-2-18, which started with an increase in its corrosion rate on day 112. Despite the increase, the specimen exhibited an $i_{\text {corr }}$ value of $0.0875 \mu \mathrm{A} / \mathrm{cm}^{2}$ by 180 days of monitoring, indicating a negligible level of corrosion. This is associated with a denser matrix and with sulfate resistance properties by replacing OPC with $10 \%$ of SCBA and $10 \% \mathrm{SF}$, this percentage has been reported as optimal for the improvement of the durability of ecological concrete, partially because of the pozzolanic reaction and partially to high specific surface area and the presence of reactive silica in the combination SCBA-SF [95].

For the specimens reinforced with AISI 304 SS, MC-2-304, M10-2-304, M20-2-304, and M30-2-304, exposed in magnesium sulfate medium ( $3.5 \mathrm{wt} . \% \mathrm{MgSO}_{4}$ solution), there is a homogeneous behavior in the four specimens, with $i_{\text {corr }}$ values less than $0.025 \mu \mathrm{A} / \mathrm{cm}^{2}$ from the start of the monitoring, which indicates a negligible level of corrosion according to Table 6. The four specimens, MC-2-304, M10-2-304, M20-2-304, and M30-2-304, display $i_{\text {corr }}$ values in the range of 0.022 to $0.011 \mu \mathrm{A} / \mathrm{cm}^{2}$ in the first 28 days (curing stage). This decrease after 98 days to $i_{\text {corr }}$ values in a range of 0.016 to $0.009 \mu \mathrm{A} / \mathrm{cm}^{2}$, owing to the formation of a denser concrete matrix caused by the formation of ettringite that fills the pore network, which some authors have identified as a greater resistance to compression [96,97]. However, after day 112, a trend is identified in the four specimens. The OPC specimen, MC-2-304, and those made with TEC, M10-2-304, M20-2-304, and M30-2-304, show an increase in $i_{\text {corr }}$ values until the end of the monitoring (180 days). In particular, the AISI 304 steel reinforced specimen that presented the greatest protection against magnesium sulfate corrosion with the lowest $i_{\text {corr }}$ values was the M20-2-304 specimen, which presented $i_{\text {corr }}$ values that varied from $0.01 \mu \mathrm{A} / \mathrm{cm}^{2}$ on day 112 to $0.024 \mu \mathrm{A} / \mathrm{cm}^{2}$ at the end of the monitoring. Next, the specimen M10-2-304, which increased from $0.016 \mu \mathrm{A} / \mathrm{cm}^{2}$ on day 98 to $0.045 \mu \mathrm{A} / \mathrm{cm}^{2}$ on day 182. The MC-2-304 and M30-2-304 specimens show very similar $i_{\text {corr }}$ values, and also presented the greatest increases in $i_{\text {corr }}$ after day 98 of exposure, with $i_{\text {corr }}$ values of $0.016 \mu \mathrm{A} / \mathrm{cm}^{2}$ and $0.017 \mu \mathrm{A} / \mathrm{cm}^{2}$ for MC-2-304 and M30-2-304, respectively. By 180 days of monitoring, the $i_{\text {corr }}$ values increased to $0.051 \mu \mathrm{A} / \mathrm{cm}^{2}$ and $0.061 \mu \mathrm{A} / \mathrm{cm}^{2}$ for MC-2-304 and M30-2-304, respectively. 


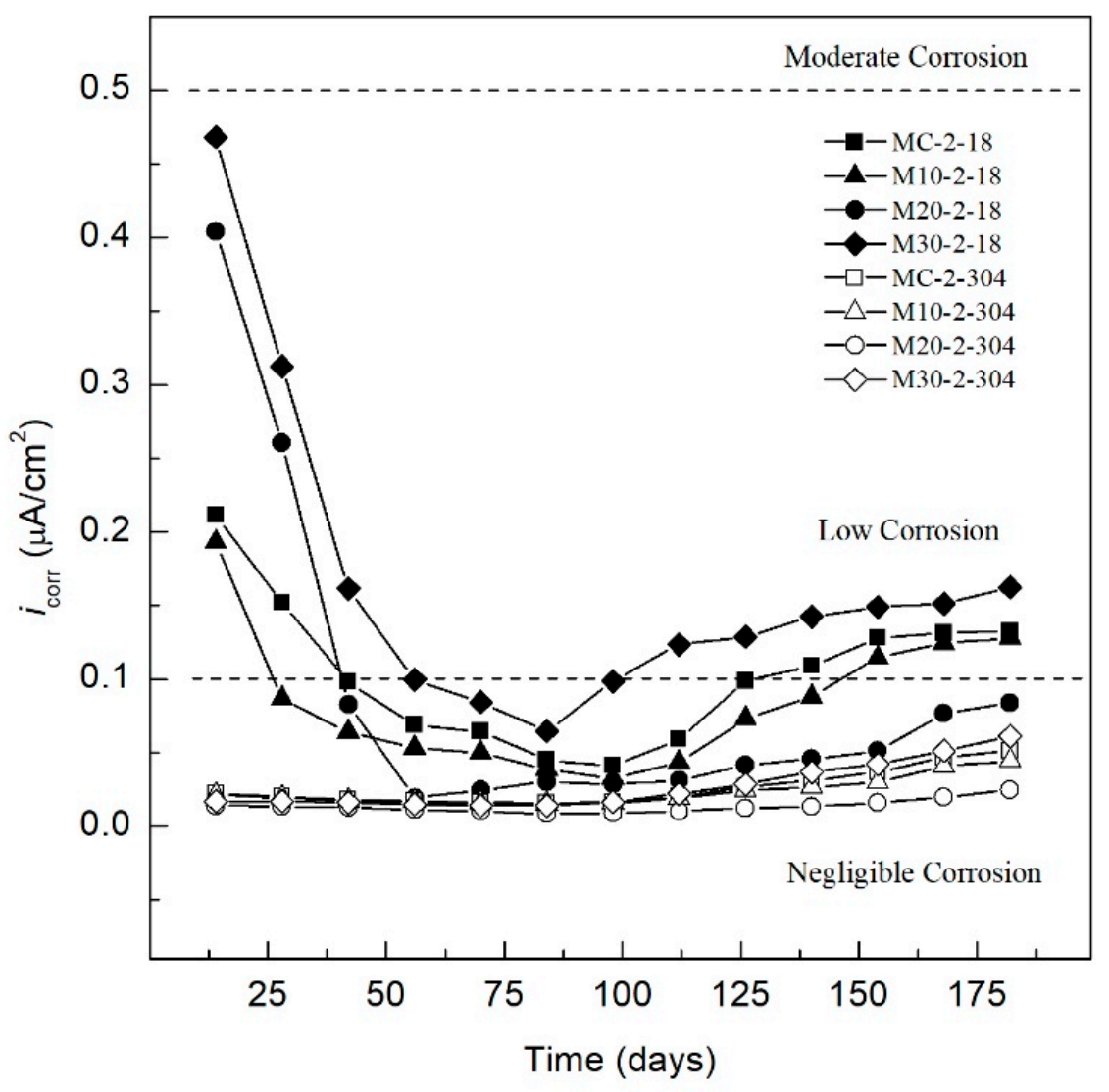

Figure 5. $i_{\text {corr }}$ specimens exposed to $3.5 \mathrm{wt} . \% \mathrm{MgSO}_{4}$ solution.

The benefit of using pozzolanic materials for protection against sulfate corrosion in reinforced concrete can be identified, with 304 SS displaying a greater protection in TEC with replacement of $20 \%$ of OPC with the combination of SCBA-SF, followed by concrete with $10 \%$ substitution. However, it should be noted that the greatest resistance to sulfate corrosion to the specimens is provided by the use of AISI 304 SS, with all specimens having values less than $0.1 \mu \mathrm{A} / \mathrm{cm}^{2}$, which indicates a negligible level of corrosion, owing to the high resistance that this steel presents when used as reinforcement in concrete, as has been shown by various investigations [98-101]. The sustainability of construction based on alternative materials to cement can be increased to produce concrete durable and resistant to corrosion by incorporating alternate reinforcements to common AISI 1018 CS has also been demonstrated by the use of galvanized steel [102].

\section{Conclusions}

The AISI 304 SS, when exposed to 3.5 wt. $\% \mathrm{MgSO}_{4}$, shows excellent corrosion performance with $E_{\text {corr }}$ values less than $-200 \mathrm{mV}$ throughout the exposure period, indicating a $10 \%$ of probability of corrosion.

The corrosion rate and $i_{\text {corr }}$ for all specimens, including OPC and TEC, show $i_{\text {corr }}$ values below $0.1 \mu \mathrm{A} / \mathrm{cm}^{2}$, thus indicating that, after 180 days of exposure to solution at $3.5 \mathrm{wt} . \%$ of $\mathrm{MgSO}_{4}$, the level of corrosion is negligible. AISI 304 SS presented better corrosion performance in TEC (M20-2-304) with an $i_{\text {corr }}$ value of $0.024 \mu \mathrm{A} / \mathrm{cm}^{2}$ at the end of the monitoring.

These results demonstrate that the development of TEC reinforced with AISI 304 SS increases the corrosion resistance when exposed to sulfated media compared with OPC and reinforced with carbon steel AISI 1018 CS. This would significantly contribute to creating a more sustainable concrete industry.

Author Contributions: Conceptualization, M.A.B.-Z., F.A.-C., and D.M.B.; Methodology, H.A.A.-F., J.B., G.S.-H., L.L.-R., M.A.B.-Z., and D.M.B.; Data Curation, J.B., H.A.A.-F., R.C., J.M.M.-R., M.A.B.-Z., J.M.B., and D.M.B.; 
Writing-Review and Editing, M.A.B.-Z., J.B., F.A.-C., and D.M.B. All authors have read and agreed to the published version of the manuscript.

Funding: This research was funded by PRODEP for the support granted by the SEP, to the Academic Body UV-CA-458 "Sustainability and Durability of Materials for Civil Infrastructure", within the framework of the 2018 Call for the Strengthening of Academic Bodies with IDCA 28593. Funding support from The University of Akron, Fellowship Program FRC-207367.

Acknowledgments: The authors thank PRODEP for the support granted by the SEP, to the Academic Body UV-CA-458 "Sustainability and Durability of Materials for Civil Infrastructure", within the framework of the 2018 Call for the Strengthening of Academic Bodies with IDCA 28593. J. Bosch and D.M. Bastidas acknowledge funding support from The University of Akron, Fellowship Program FRC-207367. The authors also thank A.C. García-Ramírez, S. Márquez-Montero, D.L. García-García, and M.I. Velásquez-Hernández for the technical support.

Conflicts of Interest: The authors declare no conflict of interest.

\section{References}

1. Cramer, S.D.; Covino, B.S., Jr.; Bullard, S.J.; Holcomb, G.R.; Russell, J.H.; Nelson, F.J.; Laylor, H.M.; Soltesz, S.M. Corrosion prevention and remediation strategies for reinforced concrete coastal bridge. Cem. Concr. Compos. 2002, 24, 101-117. [CrossRef]

2. Bastidas, D.M.; Criado, M.; Fajardo, S.; La Iglesia, A.; Bastidas, J.M. Corrosion inhibition mechanism of phosphates for early-age reinforced mortar in the presence of chlorides. Cem. Concr. Comp. 2015, 61, 1-6. [CrossRef]

3. Guneyisi, E.; Ozturan, T.; Gesoglu, M. A study on reinforcement corrosion and related properties of plain and blended cement concretes under different curing conditions. Cem. Concr. Compos. 2005, 27, 449-461. [CrossRef]

4. Ann, K.Y.; Song, H.W. Chloride threshold level for corrosion of steel in concrete. Corros. Sci. 2007, 49, 4113-4133. [CrossRef]

5. Saricimen, H.; Mohammad, M.; Quddus, A.; Shameem, M.; Barry, M.S. Effectiveness of concrete inhibitors in retarding rebar corrosion. Cem. Concr. Compos. 2002, 24, 89-100. [CrossRef]

6. Santiago-Hurtado, G.; Baltazar-Zamora, M.A.; Olguín-Coca, J.; López, L.D.; Galván-Martínez, R.; Ríos-Juárez, A.; Gaona-Tiburcio, C.; Almeraya-Calderón, F. Electrochemical Evaluation of a Stainless Steel as Reinforcement in Sustainable Concrete Exposed to Chlorides. Int. J. Electrochem. Sci. 2016, 11, 2994-3006. [CrossRef]

7. Troconis de Rincón, O.; Montenegro, J.C.; Vera, R.; Carvajal, A.M.; De Gutiérrez, R.M.; Del Vasto, S.; Saborio, E.; Torres-Acosta, A.; Pérez-Quiroz, J.; Martínez-Madrid, M.; et al. Reinforced Concrete Durability in Marine Environments DURACON Project: Long-Term Exposure. Corrosion 2016, 72, 824-833. [CrossRef]

8. Smith, F.N.; Tullmin, M. Using stainless steel as long-lasting rebar material. Mater. Perform. 1999, 38, 72-76.

9. Bertolini, L.; Pedeferri, P. Laboratory and field experience on the use of stainless steel to improve durability of reinforced concrete. Corros. Rev. 2002, 20, 129-152. [CrossRef]

10. Elsener, B.; Rossi, A. XPS investigation of passive films on amorphous FeCr alloys. Electrochim. Acta 1992, 37, 2269-2276. [CrossRef]

11. Abreu, C.M.; Cristóbal, M.J.; Losada, R.; Nóvoa, X.R.; Pena, G.; Pérez, M.C. Comparative study of passive films of different stainless steels developed on alkaline medium. Electrochim. Acta 2004, 49, 3049-3056. [CrossRef]

12. Sánchez, M.; Mahmoud, H.; Alonso, M.C. Electrochemical response of natural and induced passivation of high strength duplex stainless steels in alkaline media. J. Solid State Electrochem. 2012, 16, 1193-1202. [CrossRef]

13. Duarte, R.G.; Castela, A.S.; Neves, R.; Freire, L.; Montemor, M.F. Corrosion behavior of stainless steel rebars embedded in concrete: An electrochemical impedance spectroscopy study. Electrochim. Acta 2014, 124, 218-224. [CrossRef]

14. Mahmoud, H.; Sánchez, M.; Alonso, M.C. Ageing of the spontaneous passive state of 2304 duplex stainless steel in high-alkaline conditions with the presence of chloride. J. Solid State Electrochem. 2015, 19, $2961-2972$. [CrossRef] 
15. García-Alonso, M.C.; Escudero, M.L.; Miranda, J.M.; Vega, M.I.; Capilla, F.; Correia, M.J.; Salta, M.; Bennani, A.; González, J.A. Corrosion behaviour of new stainless steels reinforcing bars embedded in concrete. Cem. Concr. Res. 2007, 37, 1463-1471. [CrossRef]

16. Bertolini, L.; Bolzoni, F.; Pastore, T.; Pedeferri, P. Behaviour of stainless steel in simulated concrete pore solution. Br. Corros. J. 1996, 31, 218-222. [CrossRef]

17. Blanco, G.; Bautista, A.; Takenouti, H. EIS study of passivation of austenitic and duplex stainless steels reinforcements in simulated pore solutions. Cem. Concr. Compos. 2006, 28, 212-219. [CrossRef]

18. Xie, Y.; Guo, S.; Leong, A.; Zhang, J.; Zhu, Y. Corrosion behaviour of stainless steel exposed to highly concentrated chloride solutions. Corros. Eng. Sci. Technol. 2017, 52, 283-293. [CrossRef]

19. Bautista, A.; Blanco, G.; Velasco, F.; Gutierrez, A.; Palacin, S.; Soriano, L.; Takenouti, H. Passivation of duplex stainless steels in solutions simulating chloride-contaminated concrete. Mater. Construcción 2007, 57, 17-31.

20. Ormellese, M.; Berra, M.; Bolzoni, F.; Pastore, T. Corrosion inhibitors for chlorides induced corrosion in reinforced concrete structures. Cem. Concr. Res. 2006, 36, 536-547. [CrossRef]

21. Raczkiewicz, W.; Wójcicki, A. Temperature Impact on the Assessment of Reinforcement Corrosion Risk in Concrete by Galvanostatic Pulse Method. Appl. Sci. 2020, 10, 1089. [CrossRef]

22. Liang, M.T.; Lan, J.J. Reliability analysis for the existing reinforced concrete pile corrosion of bridge substructure. Cem. Concr. Res. 2005, 35, 540-550. [CrossRef]

23. Santiago, G.; Baltazar, M.A.; Galván, R.; López, L.; Zapata, F.; Zambrano, P.; Gaona, C.; Almeraya, F. Electrochemical Evaluation of Reinforcement Concrete Exposed to Soil Type SP Contaminated with Sulphates. Int. J. Electrochem. Sci. 2016, 11, 4850-4864. [CrossRef]

24. Elias, V.; Fishman, K.L.; Cristopher, B.R.; Berg, R.R. Corrosion/Degradation of Soil Reinforcements for Mechanically Stabilized Earth Walls and Reinforced Soil Slopes; U.S. Department of Transportation Publication No. FHWA-NHI-09-087, Federal Highway Administration: Washington, DC, USA, 2009.

25. Santiago-Hurtado, G.; Baltazar-Zamora, M.; Galindo, A.D.; Cabral Miramontes, J.A.; Estupiñán, F.H.L.; Robledo, P.Z.; Gaona-Tiburcio, C. Anticorrosive Efficiency of Primer Applied in Carbon Steel AISI 1018 as Reinforcement in a Soil Type MH. Int. J. Electrochem. Sci. 2013, 8, 8490-8501.

26. Ismail, A.I.M.; El-Shamy, A.M. Engineering behaviour of soil materials on the corrosion of mild steel. Appl. Clay Sci. 2009, 42, 356-362. [CrossRef]

27. Roventi, G.; Bellezze, T.; Giuliani, G.; Conti, C. Corrosion resistance of galvanized steel reinforcements in carbonated concrete: Effect of wet-dry cycles in tap water and in chloride solution on the passivating layer. Cem. Concr. Res. 2014, 65, 76-84. [CrossRef]

28. Shaheen, F.; Pradhan, B. Influence of sulfate ion and associated cation type on steel reinforcement corrosion in concrete powder aqueous solution in the presence of chloride ions. Cem. Concr. Res. 2017, 91, 73-86. [CrossRef]

29. Bellezze, T.; Malavolta, M.; Quaranta, A.; Ruffini, N.; Roventi, G. Corrosion behaviour in concrete of three differently galvanized steel bars. Cem. Concr. Compos. 2006, 28, 246-255. [CrossRef]

30. Bossio, A.; Lignola, G.P.; Fabbrocino, F.; Monetta, T.; Prota, A.; Bellucci, F.; Manfredi, G. Nondestructive assessment of corrosion of reinforcing bars through surface concrete cracks. Struct. Concr. 2017, 18, 104-117. [CrossRef]

31. Zhao, Y.; Zhang, X.; Jin, W. Influence of environment on the development of corrosion product-filled paste and a corrosion layer at the steel/concrete interface. Corros. Sci. 2017, 124, 1-9. [CrossRef]

32. Kayali, O.; Yeomans, S.R. Bond of ribbed galvanized reinforcing steel in concrete. Cem. Concr. Compos. 2000, 22, 459-467. [CrossRef]

33. Yeomans, S.R. Performance of Black, Galvanized, and Epoxy-Coated Reinforcing Steels in Chloride-Contaminated Concrete. Corrosion 1994, 50, 72-81. [CrossRef]

34. Cheng, A.; Huang, R.; Wu, J.K.; Chen, C.H. Effect of rebar coating on corrosion resistance and bond strength of reinforced concrete. Constr. Build. Mater. 2005, 19, 404-412. [CrossRef]

35. Mahasenan, N.; Smith, S.; Humphreys, K. The Cement Industry and Global Climate ChangeCurrent and Potential Future Cement Industry $\mathrm{CO}_{2}$ Emissions. In Proceedings of the Greenhouse Gas Control Technologies-6th International Conference, Kyoto, Japan, 1-4 October 2002; pp. 995-1000.

36. Habert, G.; d'Espinose de Lacaillerie, J.B.; Roussel, N. An environmental evaluation of geopolymer based concrete production: Reviewing current research trends. J. Clean. Prod. 2011, 19, 1229-1238. [CrossRef] 
37. Baltazar, M.A.; Ariza, H.; Landa, L.; Croche, R. Electrochemical Evaluation of AISI 304 SS and Galvanized Steel in Ternary Ecological Concrete based on Sugar Cane Bagasse Ash and Silica Fume (SCBA-SF) exposed to $\mathrm{Na}_{2} \mathrm{SO}_{4}$. Eur. J. Eng. Res. Sci. 2020, 5, 353-357. [CrossRef]

38. Padhi, R.; Mukharjee, B. Effect of Rice Husk Ash on Compressive Strength of Recycled Aggregate Concrete. J. Basic Appl. Eng. Res. 2017, 4, 356-359.

39. Gursel, A.P.; Maryman, H.; Ostertag, C. A life-cycle approach to environmental, mechanical, and durability properties of "green" concrete mixes with rice husk ash. J. Clean. Prod. 2016, 112, 823-836. [CrossRef]

40. Turner, L.K.; Collins, F.G. Carbon dioxide equivalent $\left(\mathrm{CO}_{2}\right.$-e) emissions: A comparison between geopolymer and OPC cement concrete. Constr. Build. Mater. 2013, 43, 125-130. [CrossRef]

41. Talha Junaid, M.; Kayali, O.; Khennane, A.; Black, J. A mix design procedure for low calcium alkali activated fly ash-based concretes. Constr. Build. Mater. 2015, 79, 301-310. [CrossRef]

42. Duxson, P.; Fernández-Jiménez, A.; Provis, J.L.; Lukey, G.C.; Palomo, A.; van Deventer, J.S.J. Geopolymer technology: The current state of the art. J. Mater. Sci. 2007, 42, 2917-2933. [CrossRef]

43. Hossain, M.M.; Karim, M.R.; Hasan, M.; Hossain, M.K.; Zain, M.F.M. Durability of mortar and concrete made up of pozzolans as a partial replacement of cement: A review. Constr. Build. Mater. 2016, 116, 128-140. [CrossRef]

44. Hussein, A.; Shafiq, N.; Nuruddin, M.F. Sudanese Sugar Cane Bagasse Ash: A Valuable by-Product for Concrete. Int. J. Struct. Civ. Eng. Res. 2018, 7, 22-28. [CrossRef]

45. Praveen, V.V.; Ravi, D. Influence of supplementary cementitious materials on strengthand durability characteristics of concrete. Adv. Concr. Constr. 2019, 7, 75-85.

46. Kupwade-Patil, K.; Allouche Erez, N. Examination of Chloride-Induced Corrosion in Reinforced Geopolymer Concretes. J. Mater. Civ. Eng. 2013, 25, 1465-1476. [CrossRef]

47. Gunasekara, C.; Law, D.W.; Setunge, S. Long term permeation properties of different fly ash geopolymer concretes. Constr. Build. Mater. 2016, 124, 352-362. [CrossRef]

48. Ganesan, N.; Abraham, R.; Deepa Raj, S. Durability characteristics of steel fibre reinforced geopolymer concrete. Constr. Build. Mater. 2015, 93, 471-476. [CrossRef]

49. Xu, H.; Van Deventer, J.S.J. Geopolymerisation of multiple minerals. Miner. Eng. 2002, 15, 1131-1139. [CrossRef]

50. Yip, C.K.; van Deventer, J.S.J. Microanalysis of calcium silicate hydrate gel formed within a geopolymeric binder. J. Mater. Sci. 2003, 38, 3851-3860. [CrossRef]

51. Navarro, R.; Alcocel, E.G.; Sánchez, I.; Garcés, P.; Zornoza, E. Corrosion resistance of steel reinforcements embedded in alkali activated ground granulated SiMn slag mortars. Constr. Build. Mater. 2020, 230, 116917. [CrossRef]

52. Manera, M.; Vennesland, Ø.; Bertolini, L. Chloride threshold for rebar corrosion in concrete with addition of silica fume. Corros. Sci. 2008, 50, 554-560. [CrossRef]

53. Lee, S.A.; Park, K.P.; Kim, J.; Ann, K.Y. Sensitivity analysis for binders in concrete mix to the corrosion risk of steel embedment in chloride-bearing environments. Constr. Build. Mater. 2020, 251, 118944. [CrossRef]

54. Heniegal, A.M.; Amin, M.; Youssef, H. Effect of silica fume and steel slag coarse aggregate on the corrosion resistance of steel bars. Constr. Build. Mater. 2017, 155, 846-851. [CrossRef]

55. Gruszczyński, M.; Lenart, M. Durability of mortars modified with the addition of amorphous aluminum silicate and silica fume. Theor. Appl. Fract. Mech. 2020, 107, 102526. [CrossRef]

56. Ganesan, K.; Rajagopal, K.; Thangavel, K. Evaluation of bagasse ash as supplementary cementitious material. Cem. Concr. Comp. 2007, 29, 515-524. [CrossRef]

57. Amin, N.U. Use of Bagasse Ash in Concrete and Its Impact on the Strength and Chloride Resistivity. J. Mater. Civ. Eng. 2011, 23, 717-720. [CrossRef]

58. Somna, R.; Jaturapitakkul, C.; Rattanachu, P.; Chalee, W. Effect of ground bagasse ash on mechanical and durability properties of recycled aggregate concrete. Mater. Des. 2012, 36, 597-603. [CrossRef]

59. Cordeiro, G.C.; Toledo Filho, R.D.; Tavares, L.M.; Fairbairn, E.M.R. Experimental characterization of binary and ternary blended-cement concretes containing ultrafine residual rice husk and sugar cane bagasse ashes. Constr. Build. Mater. 2012, 29, 641-646. [CrossRef]

60. Rukzon, S.; Chindaprasirt, P. Utilization of bagasse ash in high-strength concrete. Mater. Des. 2012, 34, 45-50. [CrossRef] 
61. Franco-Luján, V.A.; Maldonado-García, M.A.; Mendoza-Rangel, J.M.; Montes-García, P. Chloride-induced reinforcing steel corrosion in ternary concretes containing fly ash and untreated sugarcane bagasse ash. Constr. Build. Mater. 2019, 198, 608-618. [CrossRef]

62. Yashwanth, M.K.; Naresh, B.G.; Sandeep, D.S. Potential of Bagasse Ash as Alternative Cementitious Material in Recycled Aggregate Concrete. Int. J. Innov. Technol. Explor. Eng. 2019, 8, 271-275.

63. Joshaghani, A.; Moeini, M.A. Evaluating the effects of sugar cane bagasse ash (SCBA) and nanosilica on the mechanical and durability properties of mortar. Constr. Build. Mater. 2017, 152, 818-831. [CrossRef]

64. Baltazar, M.A.; Landa, A.; Landa, L.; Ariza, H.; Gallego, P.; Ramírez, A.; Croche, R.; Márquez, S. Corrosion of AISI 316 Stainless Steel embedded in Sustainable Concrete made with Sugar Cane Bagasse Ash (SCBA) exposed to marine environment. Eur. J. Eng. Res. Sci. 2020, 5, 127-131. [CrossRef]

65. Ojeda, O.; Mendoza, J.M.; Baltazar, M.A. Influence of sugar cane bagasse ash inclusion on compacting, CBR and unconfined compressive strength of a subgrade granular material. Rev. Alconpat. 2018, 8, 194-208.

66. ACI. 211.1-91 Standard. Standard Practice for Selecting Proportions for Normal, Heavyweight, and Mass Concrete; ACI: Farmington Hills, MI, USA, 2002.

67. NMX-C-414-ONNCCE-2014-Industria de la Construcción-Cementantes Hidráulicos-Especificaciones y Métodos de Ensayo; ONNCCE S.C.: México City, Mexico, 2014.

68. ASTM. C33/C33M-16e1-Standard Specification for Concrete Aggregates; ASTM International: West Conshohocken, PA, USA, 2016.

69. ASTM. C29/C29M-07-Standard Test Method for Bulk Density ("Unit Weight") and Voids in Aggregate; ASTM International: West Conshohocken, PA, USA, 2007.

70. ASTM. C127-15—Standard Test Method for Relative Density (Specific Gravity) and Absorption of Coarse Aggregate; ASTM International: West Conshohocken, PA, USA, 2015.

71. ASTM. C128-15-Standard Test Method for Relative Density (Specific Gravity) and Absorption of Fine Aggregate; ASTM International: West Conshohocken, PA, USA, 2015.

72. Baltazar, M.A.; Márquez, S.; Landa, L.; Croche, R.; López, O. Effect of the type of curing on the corrosion behavior of concrete exposed to urban and marine environment. Eur. J. Eng. Res. Sci. 2020, 5, 91-95. [CrossRef]

73. Anacta, E.T. Effect of Salt-contaminated mixing water and aggregates on time-to-initiate rebar corrosion in concrete. Int. J. Sci. Eng. Res. 2013, 4, 1524-1527.

74. Hernández, Y.; De Rincón, O.; Torres, A.; Delgado, S.; Rodríguez, J.; Morón, O. Reinforcement corrosion rate and crack width relationship in concrete beams exposed to simulated marine environment. Rev. Alconpat. 2016, 6, 271-282.

75. Dousti, A.; Moradian, M.; Taheri, S.; Rashetnia, R.; Shekarchi, M. Corrosion assessment of RC deck in a Jetty structure damaged by chloride attack. J. Perform. Constr. Facil. 2013, 27, 519-528. [CrossRef]

76. NMX-C-156-ONNCCE-2010-Determinación de Revenimiento en Concreto Fresco; ONNCCE S.C.: México City, Mexico, 2010.

77. ASTM. C 1064/C1064M-08-Standard Test Method for Temperature of Freshly Mixed Hydraulic-426 Cement Concrete; ASTM International: West Conshohocken, PA, USA, 2008.

78. NMX-C-162-ONNCCE-2014: Determinación de la Masa Unitaria, Cálculo del Rendimiento y Contenido de Aire del Concreto Fresco por el Método Gravimétrico; ONNCCE S.C.: México City, Mexico, 2014.

79. NMX-C-083-ONNCCE-2014: Determinación de la Resistencia a la Compresión de Especímenes-Método de Prueba; ONNCCE S.C.: México City, México, 2014.

80. NMX-C-159-ONNCCE-2004, Industria de la Construcción-Concreto-Elaboración y Curado de Especímenes en el Laboratorio; ONNCCE S.C.: México City, Mexico, 2004.

81. ASTM. C 876-15 — Standard Test Method for Corrosion Potentials of Uncoated Reinforcing Steel in Concrete; ASTM International: West Conshohocken, PA, USA, 2015.

82. Song, H.W.; Saraswathy, V. Corrosion Monitoring of Reinforced Concrete Structures-A Review. Int. J. Electrochem. Sci. 2007, 2, 1-28.

83. ASTM. G 59-97 (2014)-Standard Test Method for Conducting Potentiodynamic Polarization Resistance Measurements; ASTM International: West Conshohocken, PA, USA, 2014.

84. Baltazar, M.A.; Maldonado, M.; Tello, M.; Santiago, G.; Coca, F.; Cedano, A.; Barrios, C.P.; Nuñez, R.; Zambrano, P.; Gaona, C.; et al. Efficiency of Galvanized Steel Embedded in Concrete Previously Contaminated with 2, 3 and $4 \%$ of $\mathrm{NaCl}$. Int. J. Electrochem. Sci. 2012, 7, 2997-3007. 
85. Fajardo, S.; Bastidas, D.M.; Criado, M.; Romero, M.; Bastidas, J.M. Corrosion behaviour of a new low-nickel stainless steel in saturated calcium hydroxide solution. Constr. Build. Mater. 2011, 25, 4190-4196. [CrossRef]

86. Baltazar, M.A.; Santiago, G.; Moreno, V.M.; Croche, R.; De la Garza, M.; Estupiñan, F.; Zambrano, P.; Gaona, G. Electrochemical behaviour of galvanized steel embedded in concrete exposed to sand contaminated with NaCl. Int. J. Electrochem. Sci. 2016, 11, 10306-10319. [CrossRef]

87. Feliu, S.; González, J.A.; Andrade, C. Electrochemical methods for on-site determinations of corrosion rates of rebars. In Techniques to Assess the Corrosion Activity of Steel Reinforced Concrete Structures; ASTM STP 1276; Berke, N.S., Escalante, E., Nmai, C.K., Whiting, D., Eds.; ASTM International: West Conshohocken, PA, USA, 1996; pp. 107-118.

88. González, J.A.; Ramírez, E.; Bautista, A.; Feliú, S. The behaviour of pre-rusted steel in concrete. Cem. Concr. Res. 1996, 26, 501-511. [CrossRef]

89. Baltazar, M.A.; Santiago, G.; Gaona, C.; Maldonado, M.; Barrios, C.P.; Nunez, R.; Perez, T.; Zambrano, P.; Almeraya, F. Evaluation of the corrosion at early age in reinforced concrete exposed to sulfates. Int. J. Electrochem. Sci. 2012, 7, 588-600.

90. Dehwah, H.A.F.; Maslehuddin, M.; Austin, S.A. Long-term effect of sulfate ions and associated cation type on chloride-induced reinforcement corrosion in Portland cement concretes. Cem. Concr. Comp. 2002, 24, 17-25. [CrossRef]

91. Criado, M.; Bastidas, D.M.; Fajardo, S.; Fernández-Jiménez, A.; Bastidas, J.M. Corrosion behaviour of a new low-nickel stainless steel embedded in activated fly ash mortars. Cem. Concr. Comp. 2011, 33, 644-652. [CrossRef]

92. Monticelli, C.; Criado, M.; Fajardo, S.; Bastidas, J.M.; Abbottoni, M.; Balbo, A. Corrosion behavior of low Ni austenitic stainless steel in carbonated chloride-polluted alkali-activated fly ash mortar. Cem. Concr. Res. 2014, 55, 49-58. [CrossRef]

93. Fajardo, S.; Bastidas, D.M.; Ryan, M.P.; Criado, M.; McPhail, D.S.; Bastidas, J.M. Low-nickel stainless steel passive film in simulated concrete pore solution: A SIMS study. Appl. Surf. Sci. 2010, 256, 6139-6143. [CrossRef]

94. Pradhan, B. Corrosion behavior of steel reinforcement in concrete exposed to composite chloride-sulfate environment. Constr. Build. Mater. 2014, 72, 398-410. [CrossRef]

95. Alireza, S.; Amerib, F.; Dorostkarc, F.; Ahmadic, M. Rice husk ash as a partial replacement of cement in high strength concrete containing micro silica: Evaluating durability and mechanical properties. Case Stud. Constr. Mater. 2017, 7, 73-81.

96. Li, Y.; Wang, R.; Li, S.; Zhao, Y.; Qin, Y. Resistance of recycled aggregate concrete containing low-and high-volume fly ash against the combined action of freeze-thaw cycles and sulfate attack. Constr. Build. Mater. 2018, 166, 2-34. [CrossRef]

97. Wang, D.; Zhao, X.; Meng, Y.; Chen, Z. Durability of concrete containing fly ash and silica fume against combined freezing-thawing and sulfate attack. Constr. Build. Mater. 2017, 147, 398-406. [CrossRef]

98. Fajardo, S.; Bastidas, D.M.; Ryan, M.P.; Criado, M.; McPhail, D.S.; Morris, R.J.H.; Bastidas, J.M. Low energy SIMS characterization of passive oxide films formed on a low-nickel stainless steel in alkaline media. Appl. Surf. Sci. 2014, 288, 423-429. [CrossRef]

99. Baltazar, M.A.; Bastidas, D.M.; Santiago, G.; Mendoza, J.M.; Gaona, C.; Bastidas, J.M.; Almeraya, F. Effect of Silica Fume and Fly Ash Admixtures on the Corrosion Behavior of AISI 304 Embedded in Concrete Exposed in 3.5\% $\mathrm{NaCl}$ Solution. Materials 2019, 12, 4007. [CrossRef] [PubMed]

100. Bautista, A.; Blanco, G.; Velasco, F. Corrosion behaviour of low-nickel austenitic stainless steels reinforcements: A comparative study in simulated pore solutions. Cem. Concr. Res. 2006, 36, 1922-1930. [CrossRef]

101. Fajardo, S.; Bastidas, D.M.; Criado, M.; Bastidas, J.M. Electrochemical study on the corrosion behavior of a new low-nickel stainless steel in carbonated alkaline solution in the presence of chlorides. Electrochim. Acta 2014, 129, 160-170. [CrossRef]

102. Baltazar, M.A.; Mendoza, J.M.; Croche, R.; Gaona, C.; Hernández, C.; López, L.; Olguín, F.; Almeraya, F. Corrosion Behavior of Galvanized Steel embedded in concrete exposed to soil type MH contaminated with chlorides. Front. Mater. 2019, 6. [CrossRef]

(C) 2020 by the authors. Licensee MDPI, Basel, Switzerland. This article is an open access article distributed under the terms and conditions of the Creative Commons Attribution (CC BY) license (http://creativecommons.org/licenses/by/4.0/). 